\title{
ОСОБЕННОСТИ ОБУЧАНОЩЕЙ КОМПЬЮТЕРНОЙ ПРОГРАММЫ (ОГИС) ПО ЭКОЛОГИЧЕСКОМУ ОБРАЗОВАНИЮ И ВОСТИТАНИЮ ДЛЯ СРЕДНЕЙ ШКОЛЫ
}

\author{
POMAНОВ В.П., ЕРМОЛЕНКО А.В., КАРТАШЕВИЧ 3.К., \\ САМОЙЛЕНКО В.М., КИРИЛЬЧИК Л.М.
}

Белорусский государственный университет, Географический факультет, научно-исследовательская лаборатория мониторинга водных ресурсов

\section{Введение}

Экологическое воспитание и образование является одним из важнейттих направлений образовательной стратегии в Республике Беларусь. В рамках данной конщепщия, по заданию Минхстерства образования РБ, в НИЛ Мониторинга водных ресурсов создана обучающая геоинформационная система (ОГИС).

ОГИС создана на основе имеющихся в Белгосуниверситете экологических материалов по Браславскому озерному региону и предназначена для использования преподавателями и учапимися общеобразовательньх школ республики в качестве наглядного, справочного и учебного пособия при изучении природоведческих дисциплин: географии, ботаники, зоологик, общей биологии, а также информатики.

В зависимости от требований программы, а также индквидуапьньгх возможсностей, учитель может применить предоставляемый системой обтирный наглядный экологический материал на уроках биологии, географии, химии, физики, а также при организации факультативньгх занятий, олимткад, работы кружков и в проведении других мероприятий.

\section{Обиие сведения о системе}

В качестве среды функщионирования ОГИС избрана ArcView версии 2.0, являющееся однхм из лучших программных средств ГИС для ПК. ArcView способно интегрировать векторные и растровые карты, базы данных, чертежи $\mathrm{CAD}$, данные дистанционного зондирования, а также текстовые документы, отсканированные фотографии и т.д. для наглядного представления и анализа географической информации.

Основным элементом ОГИС является электронная карта центральной группы Браславских озер, полученная путем перевода в электронную форму (оцифровки) топографнческих карт М 1:200 000. Электронная карта состоит из семи слоев (таблица 1) и содержит в общей сложности свьше 500 объектов. Каждому объекту на карте сопоставлена запись в атрибутивной таблице, которая является неотьемлемой принадлежностью слоя. При этом, используя код или другие атрибуты объекта, становится возможным подключение и анализ в единой среде данных из внешнего источника - баз данньх, отсканированньгх фотографий, рисунков, текстовьхх файлов и т.д.

Атрибутивная база данных представляет собой выборку из имеющегося в НИЛ мониторинга водных ресурсов банка данных, составленного по результатам многолетних лимнологических исследований на озерах Браславской групгы. 
Таблица 1

Перечень слоев электронной карть ГИС «Браславские озера»

\begin{tabular}{|c|c|c|c|}
\hline $\begin{array}{ll}\text { № } \\
\mathrm{m} \Pi\end{array}$ & Название слоя & Oписание & Tun \\
\hline 1. & Oзepa & $\begin{array}{l}\text { Озера и пруды, плогцадью более } 0,1 \mathrm{kм}^{2} \text {; краткая } \\
\text { физико-географическая характеристхка озер. }\end{array}$ & пшошантой \\
\hline 2. & Реки & Основные реки и каналы & летвейный \\
\hline 3. & Населенные птункты & Населенные пункты (города, деревни и хутора) & ппоптадной \\
\hline 4. & Дороги & Дороги (главные, второстепенпые и местныт) & лип्йный \\
\hline 5. & Границь & Административная гранища РБ & ЛИПЕЙ̆њшй \\
\hline 6. & Точки мониторинга & Места отбора проб (воды, почвы, воздуха и др.) & точеуный \\
\hline 7. & $\begin{array}{l}\text { Достопримечательн } \\
\text { ости Браставщиныт }\end{array}$ & $\begin{array}{l}\text { Памятники природы, архитектуры их культуры. } \\
\text { "Горячая связь" для просмотра фотографй } \\
\text { достопримечательностей }\end{array}$ & точеभानाй \\
\hline 8. & $\begin{array}{l}\text { Toпографическая } \\
\text { карта }\end{array}$ & Отсканированная топографическая карта & растровый \\
\hline
\end{tabular}

\section{Использование}

В ходе разработки ОГИС специалистами НИЛ, совместно с работниками Национального института образования проведена большая работа по определению методов и подходов внедрения геоинформационных технологий в пкольный учебньй процесс; а именно:

- произведен анализ экологической направленности школьньх программ по географии для учащихся 6-10 классов общеобразовательной средней школы РБ;

- определены общеобразовательные курсы и темы занятий в средней пколе, в которьх возможно использовать элементы разработанной ОГИС, в частности: «Начальный курс географии», «Отражение поверхности земли на глобусе и карте», «Супа п водная поверхность Земли», «Рельеф земной поверхности», «Воды суши», «Погода и климат» и др.;

- определены темы и подготовлен материал для занятий в старших классах по формхрованию более сложных понятий о взаимосвязях в географической оболочке, в частности: «Формирование ледниковьх форм рельефа, образование озер и типь ледниковьг котловин», «Морфометрические особенности Браславских озер», «Формирование и расположение гидрографической сети района», «Термический режим озер», «Газовый режим озер», «Гидрохимический режим озер» и др.;

- определены темы и подготовлен материал для проведения занятий в старших классах при формировании более сложньх понятий в биологии и экологии, в частности: «Основные понятия экологии», «Структура озерной экосистемьґ», «Понятия численности и биомассы бнологических сообществ» и др.;

- разработаны критерии отбора параметров, формализованных описаний, картосхем из банка данных НИЛ Мониторинга водньх ресурсов, пригодных для внедрения в ОГИС, создан банк данжых по Браславским озерам;

- разработана и реализована в ОГИС серия тематических карт, отображающих экологическую ситуацию Браславското озерного региона;

- разработан и реализован в ОГИС ряд диаграмм, иллюстрирующих взаимосвязи между различными компонентами экосистем озер и их состояние;

- разработан и реализован в системе ряд изобразительньдх элементов, иллюстрирующих красоту Браславского края; 
- интерфейс ArcView приведен в соответствие с целями и задачами ОГИС и переведен на русских язык;

- разработана структура, создан и реализован в ОГИС гипертекстовый словарь, включающий более 300 терминов.Ниже перечислены темы занятий, при преподавании которых предлагается применение ОГИС.

- Формирование ледниковых форм рельефа.

С помощью ОГИС предлагается рассмотреть особенности строения исторюю формирования рельефа на территории Браславского поозерья: ледниковый рельеф (камы, озы, друмлины) и ледниковые отложения (конечная морена, песок, гравий), образование озер и типы озерных котловин (термокарстовые, подптрудные, эворзионные, ложбинные, сложные).

- Морфометрические особенности Браславских озер.

Рассмотреть параметры, применяемые для морфометрической характеристики озер (глубина максимальная и средняя, ширина максимальная и средняя, длина озера, изрезанность береговой линии, батиграфическая и объемная кривые, карта батщметрическая).

- Формирование и расположение гидрографической сети района.

Рассмотреть и показать с помощью ОГИС понятия «водосбор», «гидрографическая сеть», «главная река», «река», «приток», «ручей», «родник».

- Термический режим озер.

Формирование термического режима в озерах с различной глубиной (стратификация вод: эпилимнион, металимнион, гиполимнион, формирование термоклина, вертикальное распределение температуры по сезонам года).

- Газовый режим озер.

Основные растворенные газы (кислород, двуокись углерода, сероводород). Распределение кислорода по вертикали в озерах разного типа и его сезонная динамика (гомооксигения, клиноградный, негативно-гетероградный, ортоградный и позитивно-гетероградный - основные типы распределения кислорода по вертикали).

- Гидрохимический режим озер различного уровня трофии и антропогенного воздействия.

Формирование макрокомпонентного состава вод, соотношение основных ионов в озерах различного уровня трофии. Вертикальное распределение и сезонная динамика суммы и основньт ее ионов.

- Водородный показатель $(\mathrm{pH})$ в озерах разного типа, сезонная и многолетняя динамика.

С помощью графиков и диаграмм рассмотреть изменение и сезонную динамику рН в озерах разного типа.

- Органическое вещество в воде озер, его генезис, косвеннье показатели органического вещества

Сезонная и многолетняя динамика, особенности в озерах разных типов. Разложение органического вещества (деструкция), показатель загрязнения воды - БГК5, самоочищение вод.

- Прозрачность и цветность - показатели качества вод озер разньх трофицеских типов, их многолетняя и сезонная динамика.

- Понятия численности и биомассы биологических сообпеств.

В целях наиболее полного усвоения представленного материала и облегчения работы с ОГИС прилагается гипертекстовый словарь терминов, включающий свыше 
400 словоформ из областх информатики, лимнологии и физической и экономической географии.

Таким образом, применение разработанной ОГИС в школьном ухебном процессе с одной стороны - позволяет повысить эффективность изучения природоведческих дисциплин, с другой стороны - дает возможность учащимся усоверпенствовать и применить на практике знанхя по информатике.

\title{
РЕКУЛЬТИВАЦИЯ МЕЛКОВОДНЫХ ОЗЕР МЕТОДОМ ДОБЫЧИ САПРОПЕЛЕЙ
}

\author{
POМАНОВ В.П., КАРТАШЕВИЧ 3.К., САМОЙЛЕНКО В.М. \\ Белорусский государственный университет, Географический факультет, \\ научно-исследовательская лаборатория мониторинга водньх ресурсов
}

Исследования влылиия добычи сапропелей на экологию озер Беларуси показали, что при использовании экологобезопасньх способов добычи и изъятий осадков определенной мощности можно получить эффект оздоровления водоема и увеличить его экологический потенциал (Власов Б.П., Гитевич Г.С., Карташевй З.К., 1994).

Сапропелевые месторождения мелководных водоемов имеют мощность залежи более $1,5 \mathrm{M}$, а качество сапропелей большинства из них соответствует требованиям Государственного стандарта. Наиболее приемлемым для экскавации в таких условиях является экологобезопасный гидромеханизированный способ добычи.

Дистрофные водоемы практически не используются в народном хозяйстве вследствие их низкой продуктивности в условиях высокой кислотности озерных вод. Как правило, они имеют значптельные запасы высокоорганических с минеральными включениями сапропелей, которые можно использовать в качестве удобрений в сельском хозяйстве, добавок на корм скоту, при производстве строительных материалов, медицине и т.д. Многолетние наблюдения, проведенные в Белорусском государственном университете, свидетельствуют о положительных результатах экскавации в дистрофньх водоемах, которые выражаются в повышении их продуктивности. Гипертрофные озера, достигшие высокого уровня трофии в результате многократного превыпгения реальной нагрузки по фосфору над допустимой, использовать в народном хозяйстве также не представляется возможньм. Одним из надежньк способов рекультивации водоемов этого типа и восстановления кX природного потенциала изъятие по всей акватории полуметровой толщи поверхностньх донньгх отложений, обогащенньх фосфором и органикой.

Наиболее изученньмм является озеро Бецкое, которое до начала экскавации сапропелей было дистрофньм (Якушко, 1971). Добыча сапропелей в озере ведется с 1989 r. гидромеханизированным способом. К 1994 г. было изъято около 254,8 тыс.м ${ }^{3}$ органических сапропелей. Площадь разработки занимает около $60 \%$ акватории водоема. В результате экскавации максимальная глубина озера возросла с $0,5 \mathrm{~m}$ до $4 \mathrm{M}$, а объем водной массы увеличился на $20 \%$.

Трансформация гидрохимидеских и гидробиологисеских параметров приводятся по результатам исследований 1989-1994 гг. В процессе добыпи сапропеля в озере сформировались воды гидрокарбонатного класса кальциевой группы. За период 